\title{
PENGARUH PENGGUNAAN MEDIA BERVARIASI DAN MOTIVASI BELAJAR TERHADAP HASIL BELAJAR MATA PELAJARAN EKONOMI SISWA KELAS XI IPS SMA NEGERI 2 JEMBER TAHUN PELAJARAN 2016/2017
}

\author{
Rita Widiasih $^{1}$, Joko Widodo ${ }^{1}$, Titin Kartini ${ }^{1}$ \\ ${ }^{1}$ Program Studi Pendidikan, Fakultas Keguruan dan Ilmu Pendidikan, Universitas Jember \\ e-mail: jokowidodo.fkip@unej.ac.id
}

\begin{abstract}
Abstrak
Tujuan dalam penelitian ini adalah (1) untuk mengetahui pegaruh yang signifikan dari variabel penggunaan media bervariasi terhadap motivasi belajar siswa kelas XI IPS SMA Negeri 2 Jember Tahun Pelajaran 2016/2017, 2) untuk mengetahui pengaruh yang signifikan dari variabel penggunaan media bervariasi terhadap hasil belajar siswa kelas XI IPS SMA Negeri 2 Jember Tahun Pelajaran 2016/2017, 3) untuk mengetahui pengaruh yang signifikan dari variabel motivasi belajar terhadap hasil belajar siswa kelas XI IPS SMA Negeri 2 Jember Tahun Pelajaran 2016/2017 yang terdiri dari indikator yaitu pesan verbal dan nonverbal, menampilkan gambar, proyeksi gambar bergerak dan bersuara di SMA Negeri 2 Jember. Metode Penentuan lokasi penelitian menggunakan Purposive area di SMA Negeri 2 Jember di Jl. Jawa No16 Kabupaten Jember. Penentuan responden dalam penelitian ini menggunakan metode populasi yaitu sebanyak 71 siswa. Metode Pengumpulan data yang digunakan terdiri dari metode angket, wawancara, observasi dan dokumen. Analisis data yang digunakan adalah analisis jalur yaitu dengan analisis garis regresi linier yaitu dengan uji asumsi klasik, analisis jalur, uji t dan perhitungan analisis jalur. Hasil penelitian menunjukkan penggunaan media bervariasi dan motivasi belajar terhadap hasil belajar mempunyai pengaruh yang signifikan terhadap hasil belajar yaitu sebesar $0,055 \%$, sedangkan sisanya yaitu $0,045 \%$ dipengaruhi oleh variabel lainnya yang tidak diteliti dalam penelitian ini yaitu fasilitas belajar, pemahaman siswa dan minat belajar.
\end{abstract}

Kata Kunci: Penggunaan media bervariasi, motivasi belajar, hasil belajar

\section{PENDAHULUAN}

Proses pembelajaran merupakan kegiatan belajar mengajar yang menyangkut beberapa komponen dan saling terikat satu sama lain. Komponen pembelajaran tersebut diantaranya guru, siswa, materi, media, metode, kurikulum dan evaluasi. Guru sangat besar perannya dalam proses belajarmengajar yang terjadi di sekolah. Kegiatan pembelajaran disekolah merupakan salah satu kegiatan yang menentukan berhasil tidaknya proses pembelajaran yang ditandai oleh tercapainya tujuan pembelajaran dan hasil belajar siswa yang baik. Tujuan pembelajaran yang telah dirumuskan diharapkan dapat memberikan pemahaman pada siswa tentang materi yang diajarkan. Belajar adalah proses perubahan dan interaksi dengan lingkungan yang mengakibatkan terjadinya perubahan baik pengetahuan sikap, keterampilan dan perilaku yang dialami oleh siswa.

Interaksi sebagai bagian dari proses belajar siswa dan guru dalam pembelajaran dimana terjadi hubungan timbal balik diantara keduanya. Seorang guru yang baik merupakan figure yang dapat memberikan umpan balik yang bersifat positif pada siswa dalam kegiatan pembelajaran. Guru tersebut memiliki cara mengajar yang dapat menarik perhatian siswa. Cara mengajar guru yang monoton akan menimbulkan kebosanan pada siswa dan sebaliknya pembelajaran yang menarik diperlukan agar siswa tertarik untuk memperhatikan penjelasan guru. Perhatian siswa dalam pembelajaran dapat terpusat salah satunya dengan penggunaan media pembelajaran yang bervariasi. Menurut Hujair AH Sanaky (2013: 5) manfaat media pembelajaran salah satunya adalah pengajaran lebih menarik perhatian pembelajar sehingga dapat menumbuhkan motivasi belajar. 
Penggunaan media yang bervariasi akan menimbulkan semangat siswa dalam belajar. Pembelajaran akan lebih menarik jika media pembelajaran tersebut benar-benar disiapkan untuk memenuhi kebutuhan dan kemampuan siswa sehingga siswa dapat aktif berpartisipasi dalam proses belajar mengajar. Penggunaan media pembelajaran yang sesuai dalam proses belajar mengajar dapat membangkitkan motivasi dan rangsangan kegiatan belajar yang berasal dari dalam diri siswa tersebut. Siswa yang memiliki motivasi belajar yang tinggi akan bersungguh-sungguh dan bersemangat dalam belajar untuk mencapai tujuan yang diinginkan dan sebaliknya siswa yang memiliki motivasi belajar rendah cenderung malas untuk belajar.

Motivasi merupakan dorongan atau penggerak diri seseorang untuk berusaha mengadakan perubahan tingkah laku yang lebih baik dalam memenuhi kebutuhannya. Siswa yang memiliki motivasi belajar yang tinggi akan bersungguh-sungguh dan bersemangat dalam belajar untuk mencapai tujuan yang diinginkan dan sebaliknya siswa yang memiliki motivasi belajar rendah cenderung malas untuk belajar. Motivasi intrinsik yang ada pada siswa besar pengaruhnya dalam proses pembelajaran yang akan menentukan seberapa besar tingkat kemampuan siswa yang diukur dengan hasil belajar. Menurut Sardiman (2016: 85) seseorang melakukan suatu usaha karena adanya motivasi. Motivasi yang baik dalam belajar akan menunjukkan hasil yang baik. Adanya motivasi belajar pada siswa menjadikan siswa tersebut lebih bersemangat dalam belajar sehingga hasil belajar yang diperoleh dapat optimal. Hasil belajar yang diperoleh siswa tidak hanya dilihat dari aspek kognitif saja namun juga afektif dan juga psikomotorik siswa yang mengalami perubahan.

Berdasarkan hasil observasi di SMA Negeri 2 Jember dalam kegiatan belajar mengajar guru mata pelajaran ekonomi telah menggunakan media pembelajaran yang bervariasi diantaranya media audio, media visual maupun media audio visual dalam penyampaian materi pelajaran. Penggunaan media pembelajaran tersebut disesuaikan dengan materi pelajaran yang akan diajarkan. Penyesuaian penggunaan media tersebut dapat meningkatkan perhatian siswa dalam proses pembelajaran yang berlangsung sehingga siswa tidak bosan ketika pembelajaran berlangsung. Penggunaan media pembelajaran yang bervariasi secara tidak langsung akan memotivasi siswa dalam belajar. Siswa yang termotivasi untuk belajar berarti dalam diri siswa tersebut telah ada keinginan untuk belajar dengan sungguh-sungguh. Kesadaran yang berasal dari dalam diri siswa tersebut menjadikannya bersungguhsungguh dalam belajar sehingga hasil belajar yang diperoleh dapat optimal. Adanya motivasi siswa tersebut terlihat ketika dalam proses pembelajaran siswa aktif dalam menjawab pertanyaan yang diajukan guru, mengerjakan soal di papan tulis, mengajukan pertanyaan serta memperhatikan penjelasan guru.

Sesuai dengan pendapat Arikunto (2015: 131) pemahaman (comprehension) adalah dengan pemahaman, siswa diminta untuk membuktikan bahwa ia memahami hubungan yang sederhana diantara fakta- fakta atau konsep.

\section{METODE}

Jenis penelitian yang digunakan oleh peneliti adalah pendekatan yang digunakan di dalam penelitian ini adalah jenis penelitian kuantitatif. Penentuan lokasi penelitian ini menggunakan purposive area, yang ditentukan secara sengaja oleh peneliti. Penelitian ini dilakukan di SMA Negeri 2 Jember, responden penelitian adalah siswa kelas XI IPS. Dengan jumlah siswa sebanyak 70 siswa dari siswa kelas XI IPS 1 dan XI IPS 2.

Metode pengumpulan data dalam penelitian ini menggunakan angket untuk mendapatkan data tentang penggunaan media bervariasi dan motivasi belajar siswa, metode wawancara digunakan untuk mendapatkan keterangan lebih lanjut tentang pengaruh penggunaan media bervariasi dan motivasi belajar terhadap hasil belajar siswa, metode observasi digunakan untuk mendapatkan data tentang 
media yang digunakan dalam proses pembelajaran dan perilaku siswa dan metode dokumen digunakan untuk memperoleh hasil belajar siswa. Sedangkan untuk metode pengolahan data menggunakan editing, scoring dan tabulasi. Analisis data yang digunakan dalam penelitian ini yaitu analisis jalur. Uji $\mathrm{t}$ digunakan untuk mengetahui besarnya pengaruh yang signifikan masing-masing variabel penggunaan media bervariasi $(\mathrm{X})$ dan motivasi belajar $(\mathrm{Z})$ terhadap hasil belajar mata pelajaran ekonomi $(\mathrm{Y})$. Kemudian koefisien jalur yaitu untuk mengetahui berapa besar persentase $(\%)$ pengaruh penggunaan media bervariasi $(\mathrm{X})$ dan motivasi belajar $(\mathrm{Z})$ terhadap hasil belajar mata pelajaran ekonomi (Y).

\section{HASIL DAN PEMBAHASAN}

Hasil analisis jalur diketahui koefisien jalur pengaruh langsung variabel $\mathrm{X}$ terhadap $\mathrm{Z}$ sebesar 0,005 , variabel $X$ terhadap variabel $Y$ sebesar 0,023 , variabel $Z$ terhadap $Y$ sebesar 0,027 , besarnya pengaruh variabel $X$ terhaadap $Y$ melalui $Z$ sebesar 0,055 atau $55 \%$. Dan variabel lain yang tidak diteliti (ei) sebesar $45 \%$. belajar.

Hubungan antara variabel penggunaan media bervariasi dan motivasi belajar terhadap hasil

\section{Tabel}

\begin{tabular}{|c|c|c|c|}
\hline \hline Variabel & Beta & p-value & $\mathrm{A}$ \\
\hline \hline X terhadap Z & 0,334 & 0,005 & 0,05 \\
\hline \hline X terhadap Y & $-0,285$ & 0,023 & 0,05 \\
\hline \hline Z terhadap Y & 0,275 & 0,027 & 0,05 \\
\hline \hline
\end{tabular}

Berdasarkan tabel diatas diketahui bahwa besarnya $\mathrm{p}$-value $<\alpha$ dengan tingkat signifikansi $\mathrm{F}=$ $0,000<\alpha=0,05$. Hal ini menunjukkan bahwa penggunaan media bervariasi dan motivasi belajar mempunyai pengaruh yang signifikan terhadap hasil belajar. Berdasarkan data tersebut disimpulkan bahwa $\mathrm{H}_{0}$ ditolak dan $\mathrm{H}_{\mathrm{a}}$ diterima yaitu ada pengaruh yang signifikansi penggunaan media bervariasi dan motivasi belajar terhadap hasil pelajar mata pelajaran ekonomi siswa kelas XI IPS SMA Negeri 2 Jember.

Berdasarkan pada penelitian dan juga hasil analisis data yang telah dilakukan oleh peneliti, diketahui bahwa pembelajaran dengan menggunakan media pembelajaran berpengaruh pada motivasi belajar siswa. Hal ini sesuai dengan Rontree (dalam Ali Mudlofir dan Evi Fatimatur Rusydiyah, 2016: 132) bahwa fungsi media pembelajaran salah satunya adalah membangkitkan motivasi belajar. Penggunaan media pembelajaran juga berpengaruh pada hasil belajar siswa, hal ini sesuai dengan (Anam, 2016: 38) bahwa manfaat positif dari penggunaan media sebagai bagian integral pengajaran di kelas salah satunya adalah kualitas hasil belajar dapat ditingkatkan. Dan siswa yang memiliki motivasi belajar juga memperoleh hasil belajar yang baik, hal ini sesuai dengan Sardiman (dalam Iskandar 2009: 192) bahwa kegiatan pembelajaran sangat memerlukan motivasi. Hasil belajar akan menjadi optimal, kalau ada motivasi.

Berdasarkan olah data yang telah dilakukan terdapat pengaruh dari variabel penggunaan media bervariasi dan motivasi belajar terhadap hasil belajar dengan proporsi sumbangan pengaruh total sebesar $0,55 \%$, hal ini dapat diketahui bahwasanya penggunaan media bervariasi dan motivasi belajar siswa sangat mempengaruhi hasil belajar siswa. Selain itu juga terbukti dari perhitungan uji t yang digunakan untuk mengetahui pengaruh variabel bebas $(X)$, variabel intervening $(Z)$ terhadap variabel terikat $(\mathrm{Y})$, dimana $\mathrm{p}$-value $<\alpha$ dengan tingkat signifikansi $\mathrm{F}=0,000<\alpha=0,005$. Hal ini berarti bahwa 
variabel penggunaan media bervariasi dan motivasi belajar siswa mempunyai pengaruh yang signifikan terhadap hasil belajar siswa.

Penggunaan media bervariasi terkait beberapa hal yaitu pesan verbal dan nonverbal, menampilkan gambar, dan proyeksi gambar bergerak dan bersuara. Sesuai pendapat (Ali Mudlofir dan Evi Fatimatur Rusdiyah, 2016: 124) menyatakan bahwa media pembelajaran merupakan perantara atau pengantar pesan dari pengirim ke penerima agar penerima mempunyai motivasi untuk belajar sehingga diharapkan dapat memperoleh hasil belajar yang lebih memuaskan, sedangkan bentuknya bisa bentuk cetak maupun non-cetak. Berdasarkan hasil observasi dalam kegiatan pembelajaran guru telah menggunakan media yang bervariasi. Hal ini juga didukung oleh hasil wawancara yang telah dilakukan kepada salah satu siswa mengatakan bahwa:

"Kalau media yang digunakan macem-macem mbak, kadang ppt, video, gambar juga jadi tidak satu media saja" (N.17th)

Dari hasil observasi yang telah dilakukan diperoleh juga hasil bahwa motivasi belajar siswa terhadap mata pelajaran ekonomi tergolong tinggi, hal ini dapat deperkuat oleh pendapat siswa, mengatakan bahwa:

"Motivasi belajar saya tinggi karena saya suka pelajaran ekonomi karena pelajaran ekonomi itu susah-susah gampang jadi tantangan buat saya untuk belajar giat trus ekonomi itu bisa diterapkan dalam kehidupan sehari-hari terutama dalam mengelola keuangan" (D.1 $\left.7^{\text {th }}\right)$

Berdasarkan hasil dari analisis data, observasi dan wawancara yang peneliti lakukan dapat diketahui bahwa guru dan siswa SMA Negeri 2 Jember kelas XI IPS telah menggunakan media bervariasi dan motivasi belajar siswa, hal ini dapat dibuktikan sehingga permasalahan dalam penelitian ini dapat terjawab dan tujuan dalam penelitian ini dapat tercapai. Hal ini artinya hipotesis tersebut terjawab bahwa penggunaan media bervariasi dan motivasi belajar siswa berpengaruh terhadap hasil belajar mata pelajaran ekonomi siswa sebesar 55\%. Hal ini terbukti dari nilai uji t pengaruh total sebesar $55 \%$.

\section{PENUTUP}

Berdasarkan hasil analisis mengenai pengaruh penggunaan media bervariasi dan motivasi belajar siswa memberikan dampak terhadap hasil belajar mata pelajaran ekonomi. Penggunaan media bervariasi berpengaruh positif dan signifikan terhadap motivasi belajar. Penggunaan media bervariasi berpengaruh positif dan signifikan terhadap hasil belajar, dan Motivasi belajar berpengaruh positif dan signifikan terhadap hasil belajar.

Adapun saran yang diberikan dari penelitian ini yaitu pihak sekolah hendaknya terus meningkatkan sarana dan prasarana sekolah agar hasil belajar siswa SMA Negeri 2 Jember optimal. Bagi guru penggunaan media bervariasi (audio, visual maupun audio visual) dipertahankan dan dikembangkan agar motivasi dan hasil belajar siswa dapat optimal. Bagi peneliti lain, untuk ikut mempertimbangkan variabel bebas lain yang tidak diteliti dalam penelitian ini.

\section{DAFTAR PUSTAKA}

Anam, Khoirul. 2016. Pembelajaran Berbasis Inkuiri Metode dan Aplikasi. Yogyakarta: Pustaka Pelajar

Iskandar. 2009. Psikologi Pendidikan (Sebuah Orientasi Baru). Cipayung-Ciputat: Gaung Persada (GP). 
Mudlofir, Ali dan Rusydiyah, Evi, Fatimatur. 2016. Desain Pembelajaran Inovatif Dari Teori Ke Praktik. Jakarta: Rajawali Pers.

Sanaky, Hujair. AH. 2013. Media Pembelajaran Interaktif-Inovatif. Yogyakarta: Kaukaba Dipantara. Sardiman A.M. 2016. Interaksi Dan Motivasi Belajar Mengajar. Jakarta: Rajawali Pers. 